\title{
REFLEXE LISTINY ZÁKLADNÍCH PRÁV EU P̌̌I TVORBĚ VNITROSTÁTNÍ IMPLEMENTAČNÍ LEGISLATIVY V ČESKÉ REPUBLICE*
}

\author{
BOHUMIL PETERKA
}

\begin{abstract}
The Charter of Fundamental Rights of the EU in the process of Czech legislation drafting

The Charter of Fundamental Rights of the EU constitutes a principal instrument within contemporary European Union legal order. Thus, in the process of national legislation drafting it deserves substantial attention. The article outlines why, in a specific context of Czech rules on good legislation, the Charter shall be perceived as a focal point for a legislative drafter. The system of national EU law implementation process is built on both material and formal bases. The uncertainty regarding the scope of application of the Charter makes following the aforementioned system rather difficult with respect to determining whether the Charter should be taken into account or not. Following the line of the Court of Justice of the EU cases Fransson, Siragusa and Ispas, the author presents a general test which aims to help the decision.
\end{abstract}

Keywords: The Court of Justice of the EU; the Charter of Fundamental Rights of the EU; legislation; legislative drafting

Klíčová slova: Soudní dvůr EU; Listina základních práv EU; legislativa; legislativní tvorba

DOI: $10.14712 / 23366478.2018 .30$

\section{1. ÚVOD}

Regulatorní tvorba je $\mathrm{v}$ kontextu současné politické situace nepoměrně komplexnější, a tudíž i komplikovanější než v minulosti. Oblastí práva, které jsou v každém ohledu upravovány pouze na vnitrostátní úrovni, přirozeně ubývá. ${ }^{1} \mathrm{Z}$ pohledu vnitrostátního zákonodárce je ve víceúrovňovém systému normotvorby nezbytné vypořádat se jak s normami různé právní síly ve vnitrostátním právu, tak s mezinárodním právem

* Tento výstup vznikl v rámci projektu Specifického vysokoškolského výzkumu 2017-2019 s názvem „Právní vědomí: pojem, formování, účinky se zvláštním zřetelem k působení Listiny základních práv Evropské unie na právní vědomí v České republice“, č. 260 361, řešeného na Právnické fakultě Univerzity Karlovy.

1 Analýza vytvořená pro účely dolní sněmovny Spojeného království v roce 2010 dospěla k závěru, že přibližně polovina nově vytvářené britské legislativy je ovlivněna právem Evropské unie, srov. How much legislation comes from Europe? Research Paper 10/62, 13 October 2010. Dostupné z http://researchbriefings .files.parliament.uk/documents/RP10-62/RP10-62.pdf. 
v nejširším slova smyslu, ve kterém samostatnou kapitolu představuje systém Úmluvy o ochraně lidských práv a základních svobod. V neposlední řadě musí být každý návrh právního předpisu v souladu také s právem unijním, které obsahuje vlastní hierarchii norem, od „ústavní" roviny primárního práva po delegované akty. ${ }^{2}$

Tato krátká stat' se zabývá otázkami spojenými s použitelností Listiny základních práv EU (dále též „Listina“), které jsou aktuálně řešeny na celoevropské úrovni. Jejím cílem je načrtnout možné odpovědi na dvě základní otázky inherentně spojené s reflexí Listiny základních práv EU př̀ tvorbě vnitrostátní implementační legislativy: proč a kdy by mělo zhodnocení slučitelnosti návrhu vnitrostátního právního předpisu s Listinou proběhnout.

\section{ZAJIŠŤOVÁNÍ SLUČITELNOSTI - FORMÁLNÍ STRÁNKA}

Soustředíme-li se na normotvorbu se zapojením moci výkonné, hodnocení slučitelnosti legislativních návrhů s mezinárodními lidskoprávními závazky a unijním právem se dotýkají zejména tři naše národní předpisy, dva z toho účinné a jeden, který účinnosti nabude nejdř́ve 1 . ledna 2020. Tím posledně jmenovaným je nový zákon o sbírce zákonů, který poprvé na úrovni zákona stanovuje podrobná pravidla systému tvorby legislativy v České republice. Dvěma dalšími jsou platné interní předpisy exekutivy, které představují vodítka a mantinely prŕípravy návrhů právních předpisů exekutivou, tedy Legislativní pravidla vlády ${ }^{3}$ a na ně navázané Metodické pokyny pro zajišt’ování prací při plnění legislativních závazků vyplývajících z členství České republiky v Evropské unii ${ }^{4}$ (dále jen „Metodické pokyny“). ${ }^{5}$

Stěžejním v kontextu reflexe Listiny základních práv EU je na úrovni těchto vnitřních předpisů čl. 2 odst. 2 Legislativních pravidel vlády, který stanoví, že návrh musí mj. být v souladu (a) s právními předpisy vyšší právní síly a s nálezy Ústavního soudu, (b) s mezinárodními smlouvami, jimiž je Česká republika vázána a (c) s právem Evropské unie. Zajištování slučitelnosti s právem Evropské unie věnují Legislativní pravidla vlády zvláštní pozornost. Dochází k němu zaprvé materiálně - nutností komplexně popsat vztah návrhu právního předpisu k právu Evropské unie v obecné části důvodové zprávy a ve zvláštní části se pak detailněji věnovat jednotlivým ustanovením návrhu (resp. jimi implementovaným normám práva Evropské unie). ${ }^{6}$ Dále Legislativní pravidla vlády, spolu s výše zmíněnými Metodickými pokyny, rozpracovávají formální stránku vykazování slučitelnosti s právem Evropské unie. Ta spočívá v označení im-

2 Srov. napr. FOLLESDAL, A. - WESSEL, R. - WOUTERS, J.: Multilevel Regulation and the EU. The Interplay between Global, European and National Normative Processes. Nijhoff: Brill, 2008, s. 4.

3 Schválená usnesením vlády ze dne 19. března 1998 č. 188 a naposledy změněná usnesením vlády ze dne 17. ledna 2018 č. 47.

4 Schválené usnesením vlády ze dne 12. ř́jna 2005 č. 1304.

5 Přestože se jedná o pouhé vnitřní předpisy, které nemají sílu předpisů právních, na úrovni exekutivní legislativní činnosti a ve značné míře i při tvorbě legislativy v Parlamentu jsou takřka bezvýhradně respektovány.

6 Srov. vyčerpávající článek 4 odst. 5 Legislativních pravidel vlády. 
plementačních ustanovení v návrhu podtržením a připojením celexového čísla ${ }^{7}$ příslušného pramene práva Evropské unie ${ }^{8}$ a prípojením tzv. rozdílové a srovnávací tabulky k návrhu.

Rozdílová tabulka vypracovaná podle článku II odst. 2 prílohy č. 5 Legislativních pravidel vlády obsahuje na jedné straně zpravidla znění ustanovení navrženého právního předpisu ČR a na druhé straně tomu odpovídající úplné znění normativního ustanovení předpisu EU nebo charakteristiku jeho obsahu. V závěru tabulky se následně uvádí úplný výčet předpisů EU, které se navrženého předpisu dotýkají. Srovnávací tabulka je zrcadlovým odrazem tabulky rozdílové. V souladu s článkem 6a Metodických pokynů se srovnávací tabulka vypracovává ke všem předpisům práva Evropské unie a na levé straně obsahuje jednotlivá ustanovení př́islušného unijního předpisu, na straně pravé pak př́slušná implementační ustanovení ve vnitrostátním právním řádu (bez ohledu na to, zda jsou obsažena $\mathrm{v}$ již platných právních předpisech nebo $\mathrm{v}$ implementačním návrhu).

Důvody takového postupu jsou zřejmé: udržování přehledu o stavu implementace práva Evropské unie $\mathrm{v}$ České republice a jeho kontrola, a to jak v konkrétních př́padech př́pravy návrhu právního předpisu, tak průběžně, nebot' srovnávací tabulky jsou aktualizovány při každé změně implementačních předpisů. ${ }^{9}$

V neposlední řadě je nutno si uvědomit, že legislativní zajištění implementace práva Evropské unie má dvojí rovinu, pozitivní a negativní. Klasická legislativní implementace práva Evropské unie vyžaduje doplnění právního řádu o vlastní normy, které odpovídají cílům stanoveným směrnicí, nebo stanovení působnosti vnitrostátních orgánů a sankcí, které mohou být ukládány $\mathrm{k}$ efektivnímu vymáhání unijního nařízení. ${ }^{10}$ Tato pozitivní rovina představuje výraznou většinu legislativní implementační práce.

Princip negativní roviny implementace spočívá v eliminaci norem, které nejsou s právem Evropské unie v souladu. To znamená, že i když jen zrušujeme části vnitrostátního právního řádu, které by mohly být $\mathrm{v}$ rozporu $\mathrm{s}$ unijním právem, pohybujeme se v oblasti implementace práva Evropské unie, a soulad by měl být tím pádem v každém př́padě zajištěn nejen se Smlouvami a sekundárním právem či judikaturou, ale též s Listinou. ${ }^{11}$ Takový postup se uplatní především v případě primárního práva, a to zejména tam, kde se primární právo dotýká ochrany lidských práv. Zatímco totiž směrnice a nařízení požadují často pozitivní provedení vlastních ustanovení do právního řádu členského státu, režim práv ze Smluv je zpravidla negativní v tom smyslu, že si ve vnitrostátním právu vynucuje vypuštění všech omezení a diskriminačních ustanovení.

\footnotetext{
Jednoznačný identifikátor unijního právního aktu přidělený systémem Eurlex.

8 Článek II odst. 1 př́lohy č. 5 Legislativních pravidel vlády.

9 Srov. čl. 6a odst. 4 Metodických pokynů.

10 Srov. např. KRÁL, R.: Směrnice EU z pohledu jejich transpozice a vnitrostátních účinkü. Praha: C. H. Beck, 2014, s. 75.

11 K tomu více např. WHELANOVÁ, M.: Evropská dimenze tvorby práva. In Kol. aut.: Legislativní proces (teorie a praxe). Praha: Tiskárna Ministerstva vnitra, 2011, s. 501.
} 


\section{VÝKLAD ČLÁNKU 51 LISTINY - PřÍPAD FRANSSON}

To, že žádný návrh právního předpisu z těch, které promítají do českého práva požadavky práva unijního (at již pozitivním doplněním, nebo derogací) a které jsou formálně vykazované jako implementační, nesmí být s Listinou v rozporu, je tudíž zřejmé. Jedná se však o vyčerpávající výčet návrhů, které nesmí být s Listinou v rozporu? Co návrhy, které jako implementační vykázané nejsou?

Ustanovení článku 51 Listiny základních práv EU stanoví, že „Ustanovení této listiny jsou při dodržení zásady subsidiarity určena orgánům, institucím a jiným subjektům Unie, a dále členským státům, výhradně pokud uplatňují právo Unie (...) Tato listina nerozšiřuje oblast působnosti práva Unie nad rámec pravomocí Unie, ani nevytvárí žádnou novou pravomoc či úkol pro Unii, ani nemění pravomoc a úkoly stanovené ve Smlouvách“. Článek 51 tak představuje obecné ustanovení vymezující působnost Listiny. ${ }^{12}$

$\mathrm{Z}$ pohledu legislativy je pro účely reflexe Listiny primární umět odpovědět na otázku, zda návrhem dochází k implementaci práva Evropské unie, či nikoli. Jakkoli se tento problém může zdát na první pohled triviální, nalézt jeho řešení nemusí být v některých př́padech snadné ani s využitím poměrně bohaté judikatury Soudního dvora EU. Dlužno dodat, že otázka, kdy dochází k provádění práva Evropské unie, je v odborné literatuře hodnocena jako nejpalčivější z interpretačních problémů článku 51 Listiny. ${ }^{13}$

Otázku, kde leží hranice uplatňování práva Evropské unie, si můžeme pokládat především v oblasti práva procesního v případě, že unijní legislativa upravuje hmotněprávní aspekty určité materie, přičemž požaduje její efektivní výkon. Vlastní úpravu aplikačních aspektů unijního práva pak ponechává zčásti nebo zcela na libovůli vnitrostátního zákonodárce. $\mathrm{S}$ takovou situací se můžeme setkat typicky např́íklad v právu trestním, ale velká pozornost je $\mathrm{v}$ současné době $\mathrm{v}$ tomto ohledu věnována též právu daňovému.

Příkladem, značné množství trestných činů obsažených v trestním zákoníku je implementačních, nebot' jejich trestnost je požadována akty práva Evropské unie (bez ohledu na to, zda bylo unijní právo podnětem $\mathrm{k}$ jejich zavedení, nebo už v právním řádu ČR měly své místo před přijetím př́slušného aktu unijního práva). Tyto unijní hmotněprávní akty však požadují přinejmenším efektivní výkon unijního práva, který musí být přirozeně v souladu s lidskoprávními standardy unijního práva, tj. mj. těmi, které zakotvuje Listina. Tak Soudní dvůr v roce 2016 v rozsudku ve věcech Aranyosi a Căldăraru dovodil např́klad aplikovatelnost článku 4 Listiny (zákaz mučení a nelidského či ponižujícího zacházení anebo trestu) při výkonu evropského zatýkacího rozkazu, přestože podmínky ve vězeňských zařízeních per se unijní právo neupravuje. ${ }^{14}$

\footnotetext{
12 V souvislosti s uplatňováním Listiny je nutno upozornit na fakt, že významná omezení, která limitují účinek Listiny (nikoli její samotnou působnost) můžeme najít v některých ustanoveních Listiny věnovaných konkrétním právům a svobodám. Jedná se o uznání výhrady použitelnosti Listiny v souladu s ,vnitrostátními zákony a zvyklostmi“. Takové omezení nalezneme v článcích 16, 27, 28, 30, 34, 35 a 36. Stejně Soudní dvůr EU v mnohých případech v minulosti judikoval (srov. př́ipad C-317/08 - C-320/08 Alassini, ECLI:EU:C:2010:146 nebo C-93/12 ET-Agrokomsulting-04-Vrlko-Stojanov, ECLI:EU:C:2013:432), že základní práva a svobody mohou být omezovány v souladu s principem subsidiarity (s výjimkou čl. 1 až 5, nebot' se jedná o neporušitelná práva podle Úmluvy), což reflektuje následující článek 52.

13 PEERS, S. et al.: The EU Charter of Fundamental Rights. A Commentary. München: Beck, 2013, s. 1431.

14 C-404/15 a C-659/15 PPU Aranyosi a Căldăraru, ECLI:EU:C:2016:198.
} 
Základy této judikatury však byly položeny již o několik let dříve. Prvním významným př́padem, ve kterém se Soudní dvůr vyjádřil k otázce interpretace článku 51 Listiny a musel se vypořádat s otázkou šíře její působnosti, je př́pad Fransson. ${ }^{15} \mathrm{~V}$ něm se střetává právo daňové s právem trestním a zásadou ne bis in idem v situaci, kdy poplatník byl trestně stíhán za krácení daně, ačkoli již předtím byl za stejné jednání postižen správní sankcí. Soud shledal, že ačkoli vnitrostátní právní předpisy, na nichž jsou založeny uvedené daňové sankce a trestní stíhání, nebyly přijaty k provedení relevantního aktu práva Evropské unie, jeho prostřednictvím má dojít k sankcionování porušení ustanovení tohoto aktu, a tedy splnění povinnosti účinného postihu jednání ohrožujících finanční zájmy Unie, kterou Smlouva ukládá členským státům. ${ }^{16}$ Soudní dvůr EU tak dovodil, že aplikace (byt' nepř́má) unijního práva s sebou nese použitelnost základních práv zaručených Listinou. ${ }^{17}$

\section{HLEDÁNÍ TESTU PŮSOBNOSTI LISTINY}

Popis vykazování implementace unijního práva $\mathrm{v}$ České republice provedený $\mathrm{v}$ předchozím textu nebyl samoúčelný. Výše uvedené situace, v nichž lze bez větších problémů určit implementační ustanovení, podtrhnout jej a zanést do srovnávací a rozdílové tabulky, byly jednoznačné. ${ }^{18} \mathrm{Z}$ pohledu reflexe Listiny v legislativě však právě v takové jednoznačnosti nastává problém. $Z$ hlediska implementace unijního práva v České republice je nezbytné si uvědomit, že v rozsudku Fransson byla za implementační označena taková právní úprava, která by v kontextu české legislativy jako implementační formálně vykázána nebyla. ${ }^{19}$ Tudíž by slučitelnost její případné aplikace $\mathrm{s}$ Listinou nebyla posuzována $\mathrm{v}$ rámci př́pravy př́slušných právních předpisů.

Takřka „franssonovským“ př́kladem budiž návrh zákona o použití peněžních prostředků z majetkových trestních sankcí uložených v trestním řízení a o změně některých zákonů. ${ }^{20}$ Návrh původně počítal s tím, že zbydou-li na zvláštním účtu peněžní prostředky pocházející z majetkových sankcí uložených v konkrétním trestním řízení po uspokojení majetkových nároků žadatelů, zejména obětí, použijí se z nich $2 \%$ pro potřeby policejního orgánu, který vedl trestní rízení, $1 \%$ pro potřeby státního zastupitelství, které vedlo trestní řízení, a $1 \%$ pro potřeby soudu, který vedl trestní řízení. ${ }^{21}$

15 C-617/10 Akerberg Fransson, ECLI:EU:C:2013:105.

16 Tamtéž, bod 28.

17 Tamtéž, bod 21.

18 Srov. článek 9 odst. 2 Legislativních pravidel vlády a článek II př́lohy č. 5 k Legislativním pravidlům vlády.

19 Dlužno dodat, že uvedený problém je reflektován i v jiných členských státech. Srov. např. FONTANELLI, F.: The Implementation of European Union Law by Member States Under Article 5 1(1) of the Charter of Fundamental Rights. Columbia Journal of European Law, 2014, č. 20, s. 193 a násl. nebo DE MOL, M.: Articolul 51 din Carta drepturilor fundamentale a Uniunii Europene in procesele legislative ale statetor membre. R.R.D.E., 2016, č. 111.

20 Později vyhlášený pod č. 59/2017 Sb.

21 Srov. § 11 odst. 1 návrhu zákona o použití peněžních prostředků z majetkových trestních sankcí uložených $\mathrm{v}$ trestním řízení a o změně některých zákonů, zaslaný do mezirezortního př́ipomínkového řízení (materiál Ministerstva spravedlnosti, č.j.: 301/2014-L, ze dne 13. listopadu 2014). 
Cílem tohoto opatření bylo zvýšení motivace orgánů činných v trestním řízení k ukládání majetkových sankcí.

V souladu s výše uvedenou judikaturou Soudního dvora EU je však možno předloženou úpravu považovat $\mathrm{v}$ širším smyslu za implementační. Přestože přímo neprovádí žádnou normu primárního ani sekundárního unijního práva, její výkon ovlivní mj. aplikaci unijního institutu rozšířených konfiskací. ${ }^{22}$ Je proto nutno zhodnotit mj. slučitelnost návrhu s článkem 47 Listiny základních práv Evropské unie, která zakotvuje zásadu nezávislosti a nestrannosti soudů. Poté, co předkladatel provedl zhodnocení slučitelnosti návrhu s požadavkem na rozhodování věci nestranným soudem, jak je zakotven mj. v Listině základních práv EU, návrh výrazně modifikoval a důvodovou zprávu doplnil o popis relevantních úvah.

Bylo by však chybou předpokládat, že problematika působnosti Listiny, resp. vztahu práva Evropské unie a vnitrostátního práva, byla v rozsudku Fransson Soudním dvorem jednoznačně vyř̌šena. V rozsudku Siragusa ${ }^{23}$ Soudní dvůr formuloval modifikovaný test, dle kterého „,pro určení, zda vnitrostátní právní úprava spadá do uplatňování unijního práva ve smyslu článku 51 Listiny, je třeba kromě dalších skutečností ověřit, zda má uvedená vnitrostátní právní úprava za cíl provádět ustanovení unijního práva, jakou má tato právní úprava povahu a zda sleduje jiné cíle, než které zahrnuje unijní právo, i když může toto právo nepř́ímo ovlivnit, a zda existuje zvláštní ustanovení unijního práva v této oblasti nebo způsobilé ji ovlivnit“. ${ }^{24}$ Soudní dvůr dodal, že relevantním kritériem ovlivnění je jednotnost, přednost a účinnost unijního práva, resp. jejich ohrožení vnitrostátním právem. V př́padu Siragusa, který se týkal ochrany chráněné krajinné oblasti, Soudní dvůr dospěl k závěru, že Listina se neuplatní, nebot' „základní práva Unie nelze uplatnit na vnitrostátní právní úpravu z důvodu skutečnosti, že unijní ustanovení v dotyčné oblasti neukládala členským státům žádnou povinnost ohledně situace dotčené v původním řízení“. 25

I přes jisté interpretační zpřesnění, kterého se článku 51 Listiny dostalo v př́ípadu Siragusa ze strany Soudního dvora, jeho prŕstup stále nebylo možno označit za snadno aplikovatelný, zvláště pro účely legislativy. Navazující judikatura Soudního dvora se však dále pokouší o vyjasnění situace. Jedním z posledních př́ípadů, kdy se Soudní dvůr otázkou působnosti Listiny zabýval, je př́pad Ispas. ${ }^{26}$ Dosavadní judikaturu shrnuje ve svém stanovisku generálního advokáta ${ }^{27}$ (se kterým se Soudní dvůr ztotožnil) Michal Bobek, který podotýká, že „namísto hledání př́íslovečného jednorožce, v tomto př́ípadě jasně vymezeného a předvídatelného kritéria, kdy členské státy ,jednají v oblasti působnosti unijního práva' $\mathrm{v}$ situaci, kdy je prováděno či uplatňováno unijní právo, které je skutečně obtížné za současného stavu unijního práva nalézt, by Soudní dvůr měl možná přijmout koncepci odpovídající určitému ,majáku' - čím bliže je specifické

22 Směrnice Evropského parlamentu a Rady 2014/42/EU ze dne 3. 4. 2014 o zajišt’ování a konfiskaci nástrojů a výnosů z trestné činnosti v Evropské unii, Úřr. věst. L 127, 29. 4. 2014, s. 39-50.

23 C-206/13 Cruciano Siragusa v Regione Sicilia - Soprintendenza Beni Culturali e Ambientali di Palermo, ECLI:EU:C:2014:126.

24 Tamtéž, bod 25.

25 Tamtéž, bod 26.

26 C298/16 Teodor Ispas, Anduţa Ispas v Direcția Generală a Finanţelor Publice Cluj, ECLI:EU:C:2017:843.

27 C298/16 Teodor Ispas, Anduţa Ispas v Direcţia Generală a Finanţelor Publice Cluj, ECLI:EU:C:2017:650. 
a konkrétní ustanovení unijního práva, tím menší je prostor pro uvážení v rámci práva vnitrostátního“.28

V této souvislosti upravuje ve svém stanovisku (týkajícím se výběru DPH) test Soudního dvora v případu Siragusa a nabízí formulaci pravidla, podle něhož jakákoli „vnitrostátní regulace, která má zásadní význam pro účinné provedení povinnosti vycházející z unijního práva na vnitrostátní úrovni, bude spadat do oblasti působnosti unijního práva, i když nebyla přijata zvláště za výše uvedeným účelem, ledaže přijetí a fungování daného vnitrostátního pravidla není přiměřeně nezbytné $\mathrm{k}$ vynucení relevantního unijního práva“. ${ }^{29}$

\section{TEST PŮSOBNOSTI V LEGISLATIVNÍ PRAXI}

Potíž Bobkova „majákového“ pojetí pro nás tkví v tom, že příliš neusnadňuje situaci vnitrostátní legislativní praxi. ${ }^{30} \mathrm{~V}$ př́padě legislativy se totiž přirozeně kontrola slučitelnosti vnitrostátního práva nekoná až ex post, v aplikační fázi, nýbrž ex ante, ve fázi tvorby vnitrostátního práva. Můžeme se ptát, zda v hraničních př́padech, jež budou spadat především do sféry procesního práva, není třeba vycházet z presumpce působnosti práva Evropské unie. ${ }^{31}$ Vnitrostátní legislativa je totiž přirozeně schopna jen v omezené míre anticipovat budoucí normotvorbu a judikaturu na úrovni Evropské unie. Ani při vyčerpávající znalosti unijního práva by však nebylo možné předvídat veškeré aplikační situace, ke kterým může na vnitrostátní úrovni dojít. Zvláštní pozor je proto nutno dávat (plně v souladu s Bobkovým př́stupem) v pomyslných oblastech překryvu, kde je provázanost vnitrostátní a unijní právní úpravy obzvláště silná - v současné době zejména $\mathrm{v}$ již zmiňovaných oblastech práva trestního (především mezinárodní justiční spolupráce v trestních věcech), práva daňového a práva cizineckého.

Domnívám se však, že na základě dosavadní judikatury Soudního dvora je možné formulovat test, na základě kterého by legislativec mohl stanovit, zda se v oblasti působnosti práva Evropské unie pohybuje. První otázkou, kterou by si měl legislativec při př́pravě právního předpisu položit, je, zda je návrhem právního předpisu zajišt’ována legislativní, tj. formální implementace práva Evropské unie. Pokud ano, legislativa se nepochybně pohybuje v oblasti působnosti práva Evropské unie a Listiny.

V př́ipadě, že je odpověd' na první otázku negativní, následuje otázka druhá: dotýká se daný návrh materiálně, fakticky oblasti regulované právem Evropské unie? Jinými slovy, může návrh v praxi výrazným způsobem ovlivnit aplikaci unijního práva? A po-

28 Tamtéž, bod 64.

29 Tamtéž, bod 56.

30 Dlužno dodat, že to autor stanoviska sám reflektuje. Účelem řízení o předběžné otázce není, píše Bobek, „,provést abstraktní přezkum vnitrostátní právní úpravy, nýbrž vyložit unijní právo v rámci určité konkrétní věci před vnitrostátním soudem“, srov. bod 60 stanoviska.

31 Je otázkou, v jakých případech a do jaké míry se členský stát může dovolávat výhrady národní ústavní identity podle článku 4 odst. 2, resp. do jaké míry se v budoucí judikatuře Soudního dvora odrazí spíše rezervovaný prrístup zejména německého ústavního soudu k rozšiřování působnosti práva Evropské unie, podpořené využitím uvedené výhrady. Blíže KONSTADINIDES, T.: Dealing with Parallel Universes. Antinomies of Sovereignty and the Protection of National Identity in European Judicial Discourse. Yearbook of European Law, 2015, č. 1, s. 127-169. 
kud ano, může návrh nějakým způsobem provádět či ohrožovat nějaké subjektivní právo chráněné Listinou? Pokud jsou odpovědi na obě tyto otázky kladné, je nepochybné, že návrh musí být $\mathrm{v}$ souladu s Listinou, nebot' má přinejmenším potenciál $\mathrm{v}$ aplikační praxi založit rozpor s právem Evropské unie.

Takový návrh právního předpisu musí být doplněn o materiální hodnocení slučitelnosti s Listinou. Obdobně jako při hodnocení slučitelnosti návrhu s ústavním pořádkem na vnitrostátní úrovni by měl návrh v důvodové zprávě identifikovat konkrétní práva, která budou přijetím návrhu ovlivněna, př́padně by měla důvodová zpráva poskytnout výčet ustanovení Listiny, do jejichž sféry by se navrhovaná úprava mohla dostat. Je-li pro to důvod, měla by dále obsahovat úvahu předkladatele, proč není s těmito ustanoveními v rozporu. ${ }^{32}$

\section{ZÁVĚR}

Závěrem je možno shrnout, že přestože formální systém vykazování legislativního zajištění implementace práva Evropské unie v České republice je na vysoké úrovni, při identifikaci návrhů právních předpisů, které se nacházejí v oblasti působnosti práva Evropské unie s ohledem na aplikovatelnost Listiny základních práv EU, může v některých př́padech působit matoucím dojmem. Judikaturu Soudního dvora EU v tomto ohledu po rozsudku Fransson stále není možno považovat za zcela ustálenou. Pomocí analýzy relevantních rozhodnutí však lze sestavit test, který může pomoci identifikovat, kdy by v legislativní praxi bylo vhodné návrh právního předpisu zhodnotit z hlediska jeho slučitelnosti s Listinou. Uvedená rozhodnutí sice nereflektují specifika legislativní tvorby, při ní však můžeme vycházet z presumpce působnosti práva Evropské unie, což v důsledku situaci zjednodušuje.

Mgr. et Mgr. Bohumil Peterka

Právnická fakulta Univerzity Karlovy, Úřad vlády ČR

peterka.bohumil@vlada.cz

$32 \mathrm{~K}$ řádnému provedení materiálního zhodnocení slučitelnosti s Listinou analogicky POSPÍŠIL, I.: Sledování souladu legislativy s ústavním pořádkem při tvorbě práva. Správní právo, 2017, č. 3, s. 2-16. 